\title{
Demonstrating Effect of Rainfall Characteristics on Wheat Yield: Case of Sinana District, South Eastern Ethiopia
}

\author{
Fitsum Bekele ${ }^{1}$, Diriba Korecha ${ }^{2}$, Lisanework Negatu ${ }^{3}$ \\ ${ }^{1}$ National Meteorological Agency of Bale Branch Directorate, Bale-Robe, Ethiopia \\ ${ }^{2}$ USGS/Famine Early Warning Systems Network, Addis Ababa, Ethiopia \\ ${ }^{3}$ Colleague of Agriculture, Haramaya University, Haramaya, Ethiopia \\ Email: ^amake2008@gmail.com, dkorecha@fews.net, lisaneworkn@yahoo.com
}

How to cite this paper: Bekele, F., Korecha, D. and Negatu, L. (2017) Demonstrating Effect of Rainfall Characteristics on Wheat Yield: Case of Sinana District, South Eastern Ethiopia. Agricultural Sciences, 8, 371-384.

https://doi.org/10.4236/as.2017.85028

Received: March 15, 2017

Accepted: May 16, 2017

Published: May 22, 2017

Copyright ( 2017 by authors and Scientific Research Publishing Inc. This work is licensed under the Creative Commons Attribution International License (CC BY 4.0).

http://creativecommons.org/licenses/by/4.0/ (c) (i) Open Access

\begin{abstract}
Demonstrating Effects of Current and Projected Rainfall Characteristics on Wheat yield has been investigated in Sinana district for the period 1995-2016. Data on rainfall and crop yield for the period 1995-2016 were obtained from National Meteorological Agency and Sinana District Agricultural Offices, respectively. Following data quality checking, rainfall data (current and future), correlation and regression studies were analyzed using Statistical software like Instat V3.36 and SPSS V20. Downscaling the output of CSIRO-Mk3.6.0 GCM model (daily rainfall data) for RCP8.5 emission scenario using a web based software tool (Marksim GCM) for the period 2020-2049 were used to determine seasonal total rainfall and ascertain its impact on yield. This study used mean, coefficient of variation, correlation and regression analysis to ascertain the relation, cause and effect relationship between rainfall characteristics and wheat yields. The results indicated that the mean onset date of the main rainy season (JJAS) for Robe and Sinana station was June 30 and July 3. Furthermore, the results of Pearson Correlation Coefficients indicated that kiremt rainfall total (JJAS) had moderate positive relationship $(r=0.499)$ with wheat yield in the study area. It was also observed that nearly fifty percent of total variance of crop yield is explained jointly by kiremt rainfall total and rainy day $\left(\mathrm{R}^{2}\right.$ value was $\left.47.9 \%\right)$. The result of projected wheat yield indicated that there will be a slight decrease in wheat yield (qt/ha) after 2030 years due to the impact of expected weakening of kiremt rainfall total. Taking in to account the above findings, it could be suggested that the farmers' community will be encouraged encouraged to utilize timely climate information issued from $\mathrm{Na}$ tional Meteorological Agency of Ethiopia (NMA) and other centers for farm level decision to enhance their crop production.
\end{abstract}




\section{Keywords}

CSIRO-Mk3.6.0, Impact, Kiremt (JJAS), Wheat Yield

\section{Introduction}

Climate variability has always been identified as a challenge for African farmers. Specifically, it is a challenge to access climate information relevant to agricultural activities that enable the farmers to make prior decision about which crops to plant, where and when, will increase the ability of the agricultural sector to make informed decision [1]. Studies in Ethiopia have shown that rainfall variability, unreliable occurrences in sufficient amount and delay in onset dates contribute to decline in crop yields with a reasonable amount in almost all parts of the country [2]. Rainfall variability has historically been found as a major cause of food insecurity and famine in the country [3]. This is clearly due to the fact that the agricultural sector is facing increased and continued risks of climate change. It is apparent that the crop yield primarily depends on weather conditions, diseases and pests, planning of harvest operation etc. of the region. Due to this fact, effective management of these factors is necessary and used to estimate the probability of such unfavorable situation and to minimize the consequences [4]. According to World Bank [5] report, close linkage between climate and Ethiopian economy is demonstrated by the close pattern of rainfall variability and GDP growth. The trends in the contribution of agriculture to the countries total GDP clearly explain the presence of strong relationship between the performance of agriculture and climatic conditions. For instance, drought incidences that occurred during 1984/85, 1994/95 and 2000/01 years were strongly associated to nationwide famines. In contrast, good years in terms of climatic conditions of 1982/83 and 1990/91were associated with good agricultural year [6]. Most of the study revealed that agricultural sectors of the country have been highly affected by climate related hazards [7] and [8]. Annual as well as seasonal crop yield variations in Ethiopia can be partly explained by rainfall patterns. Often rainfall is the only climatic indexes that have primarily been quoted for the purpose of rainfall-yield relationship analysis [9]. For example, previous studies have shown that [10] and [11], the major causes for low productivity of the agricultural sector are traditional farming practice, low adaptive capacity, lack of awareness and climate related risks management. General Circulation Models (GCMs) describe the global climate system; representing the complex dynamics of the atmosphere, oceans, and land with mathematical equations that balance mass and energy [12] GCMs are the fundamental drivers of regional climate Change projections. GCMs allow us to characterize changes in atmospheric circulation associated with human causes at global and continental scales [13]. In order to change large-scale GCM output to a finer spatial resolution downscaling techniques must be applied to establish empirical relationships between 
GCM-resolution climate variables and local climate [14]. MarkSim is currently used to downscale outputs from GCMs and generate daily future climate data at a specific site [15]. According to [16] and [17], climate related risks such as drought (meteorological), water logging, and erratic rainfall were observed at different time in the study area, Sinana district, which was the main causes for crop failure. However, so far hardly any attempts have been made to investigate whether there exists any quantifiable relationship between some of the major crop of the region, mainly wheat and rainfall in the study area. The objectives of this study are, therefore, to identify the rainfall features and investigate its relationship with the crop of wheat and to predict the future rainfall and analyze its effect based on sensitivity of the wheat yields.

\section{Area Description}

The study area covers Sinana District, which is small portions of Southern highlands of Bale zone in Ethiopia located at $6^{\circ} 50^{\prime} \mathrm{N}-7^{\circ} 17^{\prime} \mathrm{N}$ and $40^{\circ} 06^{\prime} \mathrm{E}-40^{\circ} 24^{\prime} \mathrm{E}$ (Figure 1). It extends from 1700 to 3100 mean above sea level (m.a.s.l). This District is under Indian Ocean influences as southerly fluxes generating rainfall when strong southerly moisture flow and easterly perturbation engulf. This can be also affected by heavy rainfall events coming from northward advancement and southward retreat of ITCZ. As a result it experiences an annual average temperature of $9^{\circ} \mathrm{C}$ to $25^{\circ} \mathrm{C}$ and annual rainfall totals of between $452.7 \mathrm{~mm}$ and $1129.5 \mathrm{~mm}$, respectively. This District is bordered by Goro District in the east Dinsho District in west, Agarfa and Gassera in the north and northeast and Goba District in the south [17].

Most part of Sinana District is found in SH2 (humid sub humid to cool mild highland) agro ecology [18]. Rainfall climatologically patterns of the area also follow a bimodal distribution [19]. Agriculture is the main economic practices in the district, from which the majority of dwellers earn their livelihood income

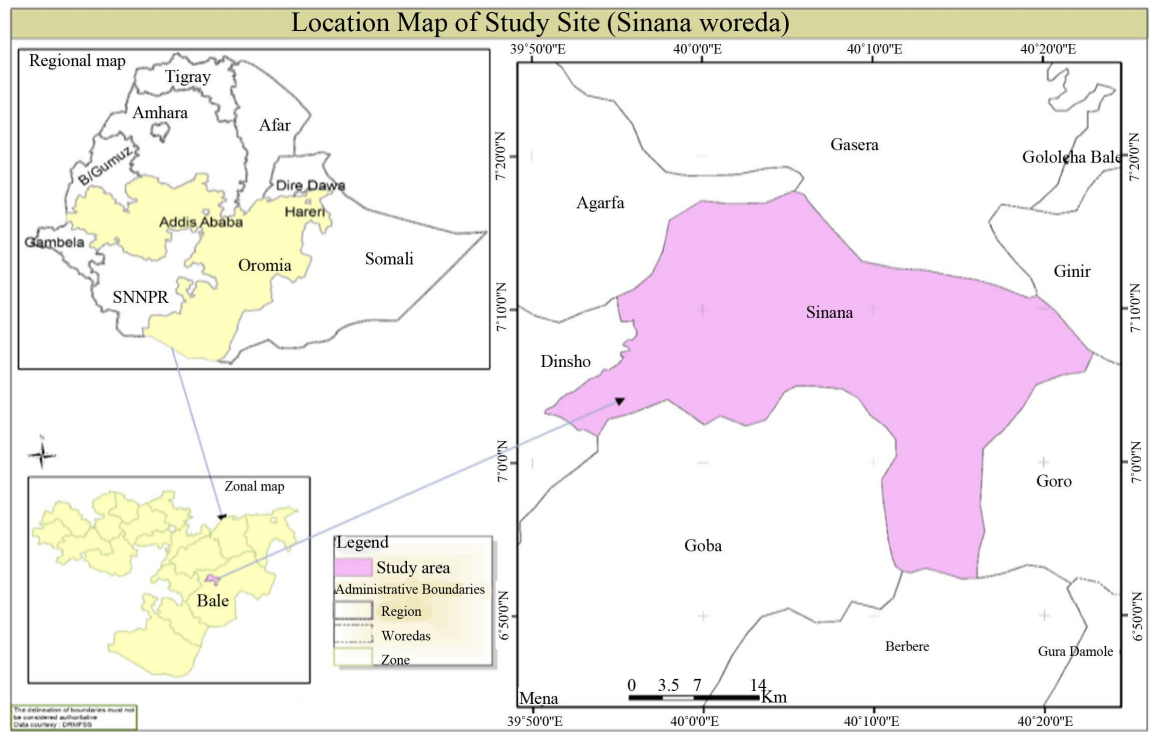

Figure 1. Map of the study area. 
mainly from crop cultivation. Major crops grow in the district include wheat, barley, oat, maize, bean and peas [20]. Topographical delineation of Sinana district includes moderate, steep slope and plateaus. Out of total land area of the District serving for crop cultivation, which is 163,554 hectares, 99,992 hectares are currently used for farm. However, there are a number of climate related hazards that are recurrent in this part of Ethiopia. As a result, of this, crop productivity is always at risk [16] and [17].

\section{Data and Methods}

\subsection{Data}

\subsubsection{Historical Rainfall and Crop Production Data}

Wheat production data for the period 1995-2016 were obtained from Sinana District Agricultural Offices (SDAO) for the Meher season (JJAS). On the other hand, rainfall data for Robe and Sinana Meteorological Stations in Sinana District for the period 1995-2016 were obtained from National Meteorological Agency of Ethiopia. In order to avoid potential problems during climate analysis, rainfall data were plotted for visual inspection and detection of outliers. Identification of outlier values should be done carefully to make sure that the outliers found is truly erroneous and is not naturally extreme values [21]. Simple statistical parameters noticeably; mean and standard deviations were computed according to their standard formula. A standard outlier threshold, which is defined using a parameter of inter-quartile range (IQR), was used for this study [22]. Mathematically, it is defined by formula as:

$$
\text { Threshold }=Q_{3}+\left(3^{*} I Q R\right)
$$

where $Q_{3}$ is third quartile and $I Q R$ is an inter-quartile range. The inter-quartile range method is known as a technique which is resistance to outliers but still keep the information of extremes [22]. The detected outlier values were removed and substituted by outlier threshold [23].

\subsubsection{Future Rainfall Data}

Future rainfall data (2020-2049) for Robe and Sinana Meteorological sites were downscaled from CSIRO-Mk 3.6.0 Atmosphere-Ocean GCM for RCP 8.5 emission scenarios of IPCC-AR5 using a web based software tool

(WWW.marksimGCM weather generator.com). Marksim is a spatially explicit daily weather generator that uses a third order Markov chain process to generate daily rainfall [24]. It requires geographical location to downscale and generate daily future data for a given site. According to [25], out of 43 models of the Coupled Model Inter-comparison Project Phase5 (CMIP5) historical experiment involved in the study CSIRO MK 3.6.0 was the only model that captures both the East African precipitation climatology and the East African long rains-SST relationship in the observation. CSIRO-Mk 3.6.0 Atmosphere-Ocean GCM was selected among the 17 GCMs due to its better estimation of areal rainfall compared to station data (2010-2016) with the aid of bar graph. 


\subsection{Methods}

\subsubsection{Determination of Rainfall Features}

In determining an onset date the one with $20 \mathrm{~mm}$ of total rainfall received over three consecutive days that were not followed by greater than 10 days of dry spell length within 30 days from planting was adopted [26]. [27] also used similar criteria, except that he used 7 day dry spell length. On the other hand, the end of the growing season is mainly dictated by stored soil water and its availability to the crop after the rain stops. In this study, the end of the rainy season was defined as any day after the first of September, when the soil water balance reaches zero [28]. In determining the end date, $3.4 \mathrm{~mm} /$ day evapotranspiration of the study site and $100 \mathrm{~mm} / \mathrm{m}$ of the plant available soil water were considered. CROPWAT 8.0 software was used to calculate evapotranspiration. Onset and cessation of rainfall date is analyzed using an Instat version 3.7 package developed by the Statistical Services Centre of the University of Reading [29]. Besides, duration of the rainy season was determined by counting the number of rainy days between the onset and the end date of the rainy season in a given time for the study area. Similarly, seasonal rainfall (kiremt rain) was decided by adding the amount of rainfall recorded for an entire season for the study area. Finally, in determining the number of rainy days, a number of different criteria are available for use. In this study however, a rainy day is defined as a period of 24 hours with at least $0.3 \mathrm{~mm}$ of recorded rainfall amount [30]. In the context of Ethiopia, [31] employed three rainfall thresholds to define a rainy day $(0.1 \mathrm{~mm}, 0.5 \mathrm{~mm}$ and $1 \mathrm{~mm}$ ). In this study, the minimum rainfall threshold definition suggested by [31], which is $0.1 \mathrm{~mm}$ per $24 \mathrm{hrs}$, was adopted.

\subsubsection{Investigation of Rainfall and Crop Yield Variability}

Standard deviation, mean and coefficient of variation were employed in investigating the variation in explanatory variables and wheat yield. Scientifically, it is calculated using the following formula:

$$
\mathrm{CV}=\left(\frac{S}{\bar{X}}\right) 100
$$

where CV is Coefficient of variation, $\mathrm{S}$ is the standard deviation and $\bar{X}$ mean for rainfall.

\subsubsection{Correlation Analysis and Construction of Statistical Model}

Correlation and multiple linear regression methods were used to establish the relationship, cause and effect of rainfall features and wheat yields. The regression equation for the study was in the form of:

$$
Y=a+b_{1} x_{1}+b_{2} x_{2}+b_{3} x_{3}+\cdots+b_{n} x+e
$$

where; $Y=$ the value of the dependent variable (wheat in qt or qt/ha); $a=Y$ intercept and $b_{1}, b_{2}, b_{3}, b_{4}, \cdots, b_{n}=$ regression coefficients, $\mathrm{x}_{1}, \mathrm{x}_{2}, \mathrm{x}_{3}, \mathrm{x}_{4}, \cdots, \mathrm{x}_{\mathrm{n}}=$ The independent variables (rainfall features such as rainfall onset, cessation, duration, seasonal rainfall total, number of rain days and yearly total rainfall respectively); and, $e=$ the error of estimate or residuals of the regression. Coefficients 
of multiple determinations $\left(R^{2}\right)$ were used to determine the percentage of variation explained jointly by the rainfall characteristics. Pearson Correlation coefficient $(r)$ analyses were used to analyze the correlation between wheat yields and rainfall features. F-distribution test was employed for testing all the coefficients in a regression model. Similarly, Student t-test in a multiple regression were employed to assess whether the independent variable adds unique and predictive value as a predictor for statistical significance [32] and [33], values were calculated using Instat package.

\subsubsection{Establish Impacts of Future Rainfall on Wheat Yields}

To determine whether the impact of future rainfall variability is increased or decreased on wheat yields, it was assessed by substituting analyzed rainfall feature variables on the developed statistical model based on sensitivity of crops after obtaining it using statistical software like Instat version 3.37 [29] and SPSS (version20).

\section{Results and Discussion}

\subsection{Correlation Analysis of Wheat Yields and Rainfall Characteristics}

As it was presented in Table 1, the correlation coefficients computed between wheat and rainfall characteristics for Robe meteorological station showed that kiremt (JJAS) rainfall total $(\mathrm{r}=0.499)$ and annual total rainfall $(\mathrm{r}=0.003)$ had positive moderate and weak correlation with wheat yields, respectively. Whereas, onset date of the rainy season $(\mathrm{r}=-0.107)$, end date of the rainy season $(\mathrm{r}=$ $-0.262)$, kiremt rainy day $(r=-0.316)$ and duration $(r=-0.144)$ had negatively weak correlation with wheat yield, respectively. In line with this result on national level [9] reported that among the rainfall characteristics studied, kiremt rainfall total had better with the value of low to moderate correlation with wheat yield.

Table 1. Pearson's lower triangular correlation matrix of rainfall features and Wheat yield for Robe Meteorological station.

\begin{tabular}{cccccccc}
\hline & $\begin{array}{c}\text { Wheat } \\
\text { yield }\end{array}$ & Onset date & $\begin{array}{c}\text { End } \\
\text { date }\end{array}$ & Duration Kiremt rain & $\begin{array}{c}\text { Kiremt } \\
\text { rainy day }\end{array}$ & $\begin{array}{c}\text { Annual total } \\
\text { rain }\end{array}$ \\
\hline $\begin{array}{c}\text { Number } \\
\text { Wheat }\end{array}$ & 22 & 22 & 22 & 22 & 22 & 22 & 22 \\
Onset & -0.107 & & & & & & \\
End & -0.262 & $0.461^{*}$ & & & & \\
Duration & -0.144 & $-0.577^{* *}$ & $0.442^{*}$ & & & \\
Kiremt rain & $0.499^{*}$ & -0.077 & 0.098 & 0.191 & & \\
Kiremt Rainy & -0.316 & -0.082 & 0.355 & 0.374 & 0.288 & & \\
day & & & & & & \\
Annual & 0.003 & -0.121 & $0.446^{*}$ & $0.574^{* *}$ & 0.387 & 0.346 & \\
\hline
\end{tabular}

${ }^{*}$ Correlation is significant at the 0.05 level (2-tailed). ${ }^{*}$ Correlation is significant at the 0.01 level (2-tailed). 
In the case of Sinana meteorological station, kiremt rainfall total $(\mathrm{r}=0.466)$, onset date $(r=0.096)$ and annual rainfall total $(r=0.003)$ had moderate and weak positive correlation with wheat yield, respectively (Table 2 ). Whereas, duration of the rainy season $(r=-0.069)$ and kiremt rainy day $(r=-0.195)$ had negative and very weak correlation with wheat yield, respectively (Table 2 ).

\subsection{Descriptive Statistics for Rainfall Characteristics and Wheat Yields}

\subsubsection{Variation in Rainfall Features and Wheat Yield}

The descriptive statistics computed for rainfall characteristics are shown in Table 3. They provide valuable explanation on existing variability in the rainfall characteristics. The mean onset date for Robe and Sinana meteorological stations is June 30 and July 3 . In fact, this result substantially agreed with the finding of [31] that indicates the mean date for the onset of the main rainy season

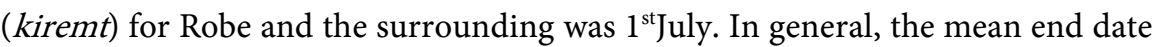
was 319 DOY ( $13^{\text {th }}$ November) for Robe. We found that this result did not agree with the finding of [31] who reported that the mean date of end of the main rainy season was October 28 . This is due to the fact that after the end of the rainy season the soil is assumed to be a field capacity of $100 \mathrm{~mm}$ so for this study in determining the end date $3.4 \mathrm{~mm}$ evapotranspiration per day of the study area and $100 \mathrm{~mm}$ of the plant available soil water were considered which is used to state the end of the growing season [28]. The highest and lowest wheat yield per hectare for Sinana district was $44.98 \mathrm{qt} / \mathrm{ha}$ in 2015 and $22.96 \mathrm{qt} / \mathrm{ha}$ in 1997. The mean yield was $32.39 \mathrm{qt} / \mathrm{ha}$ (Table 4 ).

\subsubsection{Coefficient of Variation of Rainfall Characteristics and Wheat Yield} Coefficient of variation of the rainfall characteristics for Robe meteorological station clearly demonstrates that kiremt (JJAS) rainfall total has the highest coefficient of variation (16.3\%), followed by kiremt rainy day (14\%), length of grow-

Table 2. Pearson's lower triangular correlation matrix of rainfall features and Wheat yield for Sinana Meteorological station.

\begin{tabular}{|c|c|c|c|c|c|c|c|}
\hline & $\begin{array}{l}\text { Wheat } \\
\text { yield }\end{array}$ & $\begin{array}{l}\text { Onset } \\
\text { date }\end{array}$ & $\begin{array}{l}\text { End } \\
\text { date }\end{array}$ & Duration & $\begin{array}{l}\text { Kiremt } \\
\text { rain }\end{array}$ & $\begin{array}{c}\text { Kiremt rainy } \\
\text { day }\end{array}$ & $\begin{array}{l}\text { Annual total } \\
\text { rain }\end{array}$ \\
\hline Number & 22 & 22 & 22 & 22 & 22 & 22 & 22 \\
\hline \multicolumn{8}{|l|}{ Wheat } \\
\hline Onset & 0.096 & & & & & & \\
\hline End & 0.011 & -0.305 & & & & & \\
\hline Duration & -0.069 & $-0.903^{\star *}$ & $0.684^{\star *}$ & & & & \\
\hline Kiremt rain & $0.466^{*}$ & $-0.561^{\star *}$ & $0.517^{*}$ & $0.663^{* *}$ & & & \\
\hline $\begin{array}{c}\text { Kiremt Rainy } \\
\text { day }\end{array}$ & -0.195 & $-0.502^{\star}$ & 0.150 & $0.453^{*}$ & 0.312 & & \\
\hline Annual & 0.003 & -0.206 & 0.196 & 0.246 & 0.203 & 0.297 & \\
\hline
\end{tabular}

${ }^{\star}$ Correlation is significant at the 0.05 level (2-tailed). ${ }^{\star *}$ Correlation is significant at the 0.01 level (2-tailed). 
Table 3. Descriptive statistics of rainfall features for Robe and Sinana meteorological stations.

\begin{tabular}{|c|c|c|c|c|c|}
\hline \multicolumn{6}{|c|}{ Robe Meteorological station } \\
\hline Variables & Minimum & Maximum & Mean & SD & $\mathrm{CV}(\%)$ \\
\hline Onset date (DOY) & 155 & 222 & 182 & 19 & 10.5 \\
\hline End date (DOY) & 254 & 346 & 319 & 20.5 & 6.5 \\
\hline Length of growing period (Days) & 109 & 170 & 137.7 & 19 & 13.9 \\
\hline Kiremt rainfall total (mm) & 264 & 544 & 423 & 69 & 16.3 \\
\hline Kiremt Rainy day & 48 & 85 & 67 & 9 & 14 \\
\hline Total yearly rainfall & 648.9 & 1073.8 & 838 & 110 & 13.2 \\
\hline \multicolumn{6}{|c|}{ Sinana Meteorological station } \\
\hline Variables & Minimum & Maximum & Mean & SD & $\mathrm{CV}(\%)$ \\
\hline Onset date (DOY) & 155 & 258 & 185 & 25 & 14.1 \\
\hline End date (DOY) & 299 & 346 & 324 & 15 & 4.7 \\
\hline Length of growing period (Days) & 86 & 187 & 139 & 33.9 & 24.3 \\
\hline Kiremt rainfall total (mm) & 217.4 & 854 & 440.9 & 189 & 42.9 \\
\hline Kiremt rainy day & 18 & 94 & 60 & 18.9 & 31.6 \\
\hline Total Yearly rainfall & 648.9 & 1073.8 & 838.7 & 110 & 13.2 \\
\hline
\end{tabular}

Table 4. Descriptive statistics of wheat yield in Sinana district.

\begin{tabular}{cccccccc}
\hline Variables & Minimum & Year & Maximum & Year & Mean & SD & CV (\%) \\
\hline Wheat yield (qt/ha) & 22.96 & 1997 & 44.98 & 2015 & 32.39 & 6.7 & 20.6 \\
\hline
\end{tabular}

ing period (13.9\%) and total yearly rainfall (13.2\%). An onset date of the rainy season $(10.5 \%)$ and the lowest variability of $6.5 \%$ were found in the date of end of the rainy season which indicated that the end dates of the rainy season vary over a short time span. Therefore, as less variability implies that patterns could be more understood, end of the rainy season were more reliable and predictable. Whereas the main rainy season followed by kiremt rainy day were more unreliable and unpredictable in Robe station. This finding is in line with a study conducted by [34], who reported that the total June-September rainfall over the whole regions is difficult to predict due to seasonality variability. Similarly, among the rainfall characteristics in the study for Sinana, kiremt rainfall total has the highest coefficient of variability (42.9\%), followed by kiremt rainy day (31.6\%), length of growing period (24.3\%), onset date of the rainy season (14.1\%), total yearly rainfall (13.2\%) and the lowest variability of $4.7 \%$ was found in the end date of rainy season (Table 3). As it can be inferred from Table 4, the coefficient variability of $20.6 \%$ was recorded in wheat yield per hectare. Finding [3] reported that the highest coefficient of variability that was recorded by wheat yield (14.2\%) compared with barley yield (13.5\%). This demonstrates that the highest coefficient of variation could be accounted for the joint effect by the variability in rainfall features. It should be noted that other climatic and non-climatic factors were ignored in this study. 


\subsection{Construction of Rainfall Characteristics and Wheat Yield Models}

In order to quantify physical relationship that exist between major crop and climatic events, Some of these variables were identified as explanatory variables, namely; onset date, end date, length of growing period, kiremt (JJAS) rainfall total, kiremt rainy day and total yearly rainfall. Wheat yield were regressed separately on these variables by employing stepwise regression procedure in order to see the variation in yields and the result is shown in Tables 5-8. The regression models in this case are solely developed for Robe and Sinana Meteorological station. From Table 5, the regression or prediction equation had been determined using the following equation by regressing yield (wheat yield) against selected climatic variables:

$$
Y(\text { Wheat })=30.02+0.062 \text { Total Kiremt Rain }-0.358 \text { Kiremt Rainy Day }
$$

The above regression model represents that given a unit change in any of the

Table 5. Coefficients of regression analyses for kiremt rainfall total and kiremt rainy days.

\begin{tabular}{|c|c|c|c|c|c|c|}
\hline & \multirow{2}{*}{ Model } & \multicolumn{2}{|c|}{ Unstandardized Coefficients } & \multirow{2}{*}{$\begin{array}{c}\text { Standardized } \\
\text { Coefficients } \\
\text { Beta }\end{array}$} & \multirow[t]{2}{*}{$\mathrm{t}$} & \multirow{2}{*}{ Sig. } \\
\hline & & B & Std. Error & & & \\
\hline \multirow{3}{*}{1} & (Constant) & 30.020 & 9.275 & & 3.237 & 0.004 \\
\hline & Kiremt rain & 0.062 & 0.017 & 0.643 & 3.717 & 0.001 \\
\hline & $\begin{array}{c}\text { Kiremt Rainy } \\
\text { day }\end{array}$ & -0.358 & 0.123 & -0.501 & -2.898 & 0.009 \\
\hline
\end{tabular}

a. Dependent Variable: Wheat.

Table 6. Regression values for predictors.

\begin{tabular}{ccccc}
\hline Model & $\mathrm{R}$ & R Square & Adjusted R Square & Std. Error of the Estimate \\
\hline 1 & $0.692^{\mathrm{a}}$ & 0.479 & 0.424 & 5.0755144 \\
\hline
\end{tabular}

a. Predictors: (Constant), Kiremt rain, Kiremt rainy day.

Table 7. Coefficients of regression analyses for kiremt rainfall total and duration.

\begin{tabular}{|c|c|c|c|c|c|c|}
\hline & \multirow{2}{*}{ Model } & \multicolumn{2}{|c|}{ Unstandardized Coefficients } & \multirow{2}{*}{$\begin{array}{c}\text { Standardized } \\
\text { Coefficients } \\
\text { Beta }\end{array}$} & \multirow{2}{*}{$\mathrm{t}$} & \multirow{2}{*}{ Sig. } \\
\hline & & B & Std. Error & & & \\
\hline \multirow{3}{*}{1} & (Constant) & 36.681 & 4.750 & & 7.723 & 0.000 \\
\hline & Krain & 0.032 & 0.008 & 0.912 & 4.097 & 0.001 \\
\hline & Duration & -0.133 & 0.044 & -0.673 & -3.024 & 0.007 \\
\hline
\end{tabular}

a. Dependent Variable: wheat.

Table 8. Regression values for predictors.

\begin{tabular}{ccccc}
\hline Model & $\mathrm{R}$ & R Square & Adjusted R Square & Std. Error of the Estimate \\
\hline 1 & $0.687^{\mathrm{a}}$ & 0.472 & 0.416 & 5.1116327
\end{tabular}

a. Predictors: (Constant), Kiremt rainfall, Duration 
rainfall characteristics included in the study above while holding either of them constant, the highest variation in yield of wheat in the area will be experienced by kiremt rainfall total ( $0.062 \mathrm{qt} / \mathrm{ha})$, followed by the least change in yield will be from kiremt rainy day $(-0.358 \mathrm{qt} / \mathrm{ha})$. These result shows that among the rainfall characteristics included in the study, kiremt rainfall total $\left(\mathrm{x}_{1}\right)$ is the most important variable that has significant impact on wheat yield in the study area indicating that the yield of wheat is higher when kiremt rainfall total is getting higher. In contrast, kiremt rainy day has a negative impact on yield of wheat, meaning that there was higher yield of wheat under years with lower seasonal kiremt rainy days. Furthermore, statistical t-test analysis indicates that among the rainfall characteristics included in the study, only kiremt rainfall total $\left(\mathrm{x}_{1}\right)$ and $k i$ remt rainy day $\left(\mathrm{x}_{2}\right)$ are statistically significant in influencing wheat yield positively and negatively at 0.05 confidence level, respectively. The computed value for coefficient of multiple determinations $\left(\mathrm{R}^{2}\right)$ is 0.479 (Table 6). This means that $47.9 \%$ of the variations on wheat yield per hectare for the past 22 years in Sinana district. That is, nearly fifty percent of total variance of crop yield is explained jointly by kiremt rainfall total and kiremt rainy day. The remaining $52.1 \%$ of the variation in wheat yield, however, could be explained by other climatic and non-climatic factors. [9] Also found similar result in 3 provinces of Ethiopia that Yield variability in Ethiopia agriculture can be partly explained by rainfall.

From Table 7, the regression or prediction equation had been determined using the following equation by regressing yield (wheat yield) against selected climatic variables:-

$$
Y(\text { Wheat })=36.681+0.032 \text { kiremt rain }-0.133 \text { duration }
$$

The above prediction model represents that given a unit change in any of the rainfall characteristics included in the study while holding either constant, the highest variation in yield of wheat in the area will be accounted by kiremt rainfall total ( $0.032 \mathrm{qt} / \mathrm{ha})$, followed by the least change in yield will be from duration of the rainy season $(-0.133 \mathrm{qt} / \mathrm{ha})$. These result show that among the rainfall characteristics included in the study, kiremt rainfall total $\left(\mathrm{x}_{2}\right)$ is the most important variable that has significant impact on wheat yield in the study indicating that the yield of wheat is higher when kiremt rainfall total is getting higher. In contrast, duration of the rainy season has a negative impact on yield of wheat, meaning that there was higher yield of wheat under years with lower duration of rainy season. Furthermore, statistical t-test analysis indicates that among the rainfall characteristics included in the study only duration of the rainy season $\left(\mathrm{x}_{2}\right)$ and kiremt rainfall total $\left(\mathrm{x}_{1}\right)$ are statistically significant in influencing wheat yield negatively and positively at 0.05 confidence level, respectively. The computed value for coefficient of multiple determinations $\left(\mathrm{R}^{2}\right)$ is 0.472 (Table 8). This means that $47.2 \%$ of the variations on wheat yield per hectare for the past 22 years in Sinana district, That is, nearly fifty percent of total variance of crop yield are explained jointly by kiremt rainfall total and duration of kiremt rainy season. The remaining $52.8 \%$ of the variation in wheat yield, however, could be 
explained by other climatic and non-climatic factors.

\subsection{Projected Impact of Rainfall Characteristics on Wheat Yield}

To ensure whether future rainfall change impact wheat yields, the following regression model was developed based on sensitivity of crops for some potential climatic features (Table 9). $X_{1}$ (Kiremt rainfall total) in the first prediction model of table below will have a projected value of $385.3,385$ and $343.4 \mathrm{~mm}$ rainfall amount by the year 2020, 2030 and 2049 respectively. Similarly, $X_{2}$ (Number of rainy days during kiremt season) in the first prediction model of table below will have a projected value of 41, 41 and 42 days by 2020, 2030 and 2049 respectively. Substituting this value in the first prediction model the projected wheat yield in qt/ha will be $39.23 \mathrm{qt} / \mathrm{ha}, 39.21 \mathrm{qt} / \mathrm{ha}$ and $36.27 \mathrm{qt} / \mathrm{ha}$ by 2020,2030 and 2049 years, respectively. Similarly, Substituting the second values of $\mathrm{X}_{1 \text { and }} \mathrm{X}_{2}$ in the second predication model of Table 9 , the predicted wheat yield in $\mathrm{qt} / \mathrm{ha}$ will be $33.98 \mathrm{qt} / \mathrm{ha}, 34.01 \mathrm{qt} / \mathrm{ha}$ and $30.95 \mathrm{qt} / \mathrm{ha}$ by 2020, 2030, and 2049 years respectively. Due to the impact of expected weakening of kiremt rainfall total after 2030 the result of projected wheat yield indicated that there will be a slight decrease in wheat yield (qt/ha) after 2030 years in the study area. Similar results in yield reduction were reported in Oromia Regional State and national level [3]. His finding dictated that percentage change in mean wheat yield over Oromia and Ethiopia will be -7.26 and -6.21 for the year 2050, respectively.

\section{Conclusions}

This study was undertaken to investigate the relationship of wheat yield and rainfall characteristics using global circulation model output and ascertain its impact on wheat yield. Analysis of rainfall characteristics (for Robe and Sinana meteorological stations) and wheat yield were undertaken for the period 1995-2016. Correlation coefficient values revealed that among the rainfall characteristics studied kiremt (JJAS) rainfall total and onset had positive moderate to weak correlation with wheat yield in the study area. On the other hand, the study developed a regression model to account for the impact of rainfall characteristics on wheat yield in the study site. Hence duration of the main rainy season, kiremt rainfall total and kiremt rainy days were identified as potential predictors for wheat yield compared to other variables included in the study. The result showed that wheat yield was influenced negatively and positively by duration of the rainy season, kiremt rainy days and kiremt rainfall total, respectively. Output from single global circulation model, CSIRO for RCP 8.5 scenario is used

Table 9. Statistical models for the projected impact of rainfall characteristics on wheat yield at Sinana district.

\begin{tabular}{ccc}
\hline $\begin{array}{c}\text { Name of } \\
\text { Stations }\end{array}$ & $\begin{array}{c}\text { Statistical } \\
\text { Prediction Model }\end{array}$ & $\begin{array}{c}\text { Projected values of rainfall } \\
\left(\mathrm{X}_{1} \text { and } \mathrm{X}_{2} \text { in } \mathrm{mm}\right) \text { in } 2020,2030 \text { and 2049 years }\end{array}$ \\
\hline Robe & $\begin{array}{c}\text { Y (Wheat })=30.02+0.062 \text { total } \\
\text { kiremt rain }-0.358 \text { kiremt rainy day } \\
\text { Sinana }\end{array}$ & $(385.3,385,343.4)$ and $(41,41,42)$ \\
& $\begin{array}{c}\text { kiremt rain }-0.133 \text { duration } \\
\text { kireat }=36.681+0.032\end{array}$ & $(431,402.9,402.9)$ and $(124,117,140)$
\end{tabular}


used for this study to generate rainfall and also to ascertain its impact based on sensitivity of crops to rainfall features. kiremt rain over both Robe and Sinana meteorological stations showed that kiremt rain will be decreased under RCP 8.5 scenario after 2030. The descriptive statistics of rainfall characteristics revealed that the mean onset date of the main rainy season (kiremt) was June 30 and July 3 for Robe while the end date was $13^{\text {th }}$ and $16^{\text {th }}$ November for Robe and Sinana meteorological stations, respectively. Furthermore, coefficient of variation of the rainfall characteristics showed that among the six rainfall characteristics studied, kiremt rain had the highest coefficient of variability while end date of the main rainy season exhibited the least coefficient of variability. Due to this fact, it can be concluded that kiremt rain is not easily predicted while the patterns of end date of the rainy season can be easily understood.

The result of projected wheat yield indicated that there will be a slight decrease (qt/ha) after 2030 years due to the impact of expected weakening of $k i$ remt rainfall total.

\section{Acknowledgements}

Above all, I would like to thank the almighty God and her mother virgin merry for providing me Good Health. I would like to express my heartfelt thanks to my major advisor, Dr. Diriba Korecha for his encouragement and advice during my master's work. My grateful appreciation is extended to my Co-advisor Assoc. Prof. Lisanework Nigatu, for his useful comments and boundless assistance throughout my study period. I am greatly indebted to National Meteorological Agency of Ethiopia for giving me a study leave; and RUFORUM through Haramaya University for granting me the research fund (thesis). Finally, special thanks goes to my family Amakelech (Emewedesh) my beloved mother and my sisters Marefia, Meresha and Hiwot who helped me gratefully to concentrate on my studies.

\section{References}

[1] Zermoglio, M.F. (2011) Climate Information to Support Adaptation Decisions in Africa. Technical Report to International Resources Group and U.S. Agency for International Development.

[2] Makombe, G., Kelemework, D. and Aredo, D. (2007) A Comparative Analysis of Rainfed and Irrigated Agricultural Production in Ethiopia. Irrigation and Drainage Systems, 21, 35-44.

[3] Beweket, W. (2009) Rainfall Variability and Crop Production in Ethiopia Case Study in the Amhara Region. Department of Geography and Environmental Studies, Addis Ababa University.

[4] Raorane, A.A. and Kulkarni, R.V. (2012) Data Mining: An Effective Tool for Yield Estimation in the Agricultural Sector. Report of the Intergovernmental Panel on Climate Change, Cambridge University Press, Cambridge.

[5] World Bank (2006) Managing Water Resources to Maximize Sustainable Growth: A World Bank Water Resources Assistance Strategy for Ethiopia. A Country Water Resources Assistance Strategy. World Bank, Washington DC.

[6] Deressa, T.T. (2006) Measuring the Economic Impact of Climate Change on Ethio- 
pian Agriculture: Ricardian Approach. CEEPA DP25, University of Pretoria, South Africa.

[7] NMA (2001) Initial National Communication of Ethiopia to the United Nations Frame-Work Convention on Climate Change (UNFCCC). Addis Ababa, Ethiopia.

[8] Deressa, T.T. (2007) Measuring the Economic Impact of Climate Change on Ethiopian Agriculture: Ricardian Approach. World Bank Policy Research Working Paper No. 4342, World Bank, Washington DC.

[9] Lemi, A. (2005) Rainfall Probability and Agricultural Yield in Ethiopia. Eastern Africa Social Science Review, 21, 57-96. https://doi.org/10.1353/eas.2005.0004

[10] NMA-NAPA (2007) Climate Change National Adaptation Program of Action (NAPA) of Ethiopia. Ministry of Water Resources, Addis Ababa.

[11] Deressa, T.T., Hassan, R.M., Ringler, C., Alemu, T. and Yesuf, M. (2009) Determinants of Farmers' Choice of Adaptation Methods to Climate Change in the Nile Basin of Ethiopia. Global Environmental Change, 19, 248-255.

[12] IPCC (2007) Climate Change 2007: The Physical Science Basis. Contribution of Working Group I to the Fourth Assessment Report of the Intergovernmental Panel on Climate Change. Cambridge University Press, Cambridge, UK and New York, USA.

[13] Cayan, D., et al. (2013) Future Climate: Projected Average. In: Garfin, G., Jardine, A., Merideth, R., Black, M. and LeRoy, S., Eds., Assessment of Climate Change in the Southwest United States: A Report Prepared for the National Climate Assessment, Southwest Climate Alliance, Island Press, Washington DC, 101-125. https://doi.org/10.5822/978-1-61091-484-0_6

[14] Green, T.R., Taniguchi, M., Kooi, H., Gurdak, J.J., Allen, D.M., Hiscock, K.M., Treidel, H. and Aureli, A. (2011) Beneath the Surface of Global Change: Impacts of Climate Change on Groundwater. Journal of Hydrology, 405, 532-560.

[15] Jones, P.G. and Thornton, P.K. (2013) Generating Downscaled Weather Data from a Suite of Climate Models for Agricultural Modeling Applications. Agricultural Systems, 114, 1-5.

[16] Bessie, S. (2010) Input Supply and Output Marketing Role of Multipurpose Cooperatives in Increasing Cereal Production in Bale Zone (Oromia Regional State), Ethiopia. MSc Thesis, Addis Ababa University, Addis Ababa.

[17] SDAO (2006) Sinana District Agricultural Office, Annual Physical Year Report, Documented File, Bale-Robe.

[18] MoA (Ministry of Agriculture) (2000) Agro-Ecological Zonation's of Ethiopia. Addis Ababa, Ethiopia.

[19] NMSA (1996) Climate \& Agro Climate Resources of Ethiopia. NMSA Meteorological Research Report Series, Vol. 1, No. 1, and Addis Ababa.

[20] Bogale, S., Solomon, M. and Yami, A. (2009) The Interdependence of Crop-Livestock Production Sectors: The Case of Sinana Dinsho District in Bale Highlands of Ethiopia. Agricultura Tropica et Subtropica, 42, 65-71.

[21] Abbas, F., Ahmad, A., Safeeq, M., Ali, S., Saleem, F., Hammad, H.M. and Farhad, W. (2013) Changes in Precipitation Extremes over Arid to Semiarid and Subhumid Punjab, Pakistan. Theoretical and Applied Climatology, 116, 671-680.

[22] Gonzalez-Rouco, J.F., Jimenez, J.L., Quesada, V. and Valero, F. (2001) Quality Control and Homogeneity of Precipitation Data in the South West of Europe. Journal of Climate, 14, 967-978. https://doi.org/10.1175/1520-0442(2001)014<0964:QCAHOP >2.0.CO;2

[23] SUPARI (2012) Spatiotemporal Characteristics of Extreme Rainfall Events over Java 
Island. Submitted to M.Sc Program, Faculty of Geo-Information and Earth Observation, University of Twente, Enschede.

[24] Jones, P.G. and Thornton, P.K. (2000) MarkSim: Software to Generate Daily Weather Data for Latin America and Africa. Agronomy Journal, 9, 445-453. https://doi.org/10.2134/agronj2000.923445x

[25] Yang, W., Seager, R., Cane, M.A. and Lyon, B. (2014) The East African Long Rains in Observations and Models. Journal of Climate, 27, 7185-7202.

[26] Raman, C.V.R. (1974) Analyses of Commencement of Monsoon Rains over Maharashtra State for Agricultural Planning. Scientific Report 216, India Meteorological Department, Poona, India.

[27] Sivakumar, M.V.K. (1988) Predicting Rainy Season Potential from the Onset of Rains in Southern Sahelian and Sudanian Climatic Zones of West Africa. Agricultural and Forest Meteorology, 42, 295-305.

[28] Stern, R.D. and Coe, R. (1982) The Use of Rainfall Models in Agricultural Planning. Agricultural Meteorology, 26, 35-50.

[29] Stern, R., Rijks, D., Dale, I. and Knoch, J. (2006) Instat Climatic Guide. Statistical Services Center, Reading University, Reading, UK.

[30] Stocker, T.F., et al., Eds., IPCC (2013) Climate Change 2013: The Physical Science Basis. Contribution of Working Group I to the Fifth Assessment Report 1 of the Intergovernmental Panel on Climate Change. Cambridge University Press, Cambridge and New York, $1535 \mathrm{p}$.

[31] Segele, Z.T. and Lamb, P.J. (2005) Characterization and Variability of Kiremt Rainy Season over Ethiopia. Meteorology and Atmospheric Physics, 89, 153-180. https://doi.org/10.1007/s00703-005-0127-x

[32] Agrawal, R., Jain, R.C. and Jha, M.P. (1986) Models for Studying Rice CropWeather Relationship. Mausam, 37, 67-70.

[33] Odekunle, T.O., Orinmoogunje, I.O. and Ayalande, A. (2007) Application of GIS to Assess Rainfall Variability impact on Crop Yield in Guinea Savanna Part of Nigeria. Journal of Biotechnology, 6, 2100-2113.

[34] Gissila, T., Black, E., Grimes, D.I.F. and Slingo, J.M. (2004) Seasonal Forecasting of the Ethiopian Summer Rains. International Journal of Climatology, 24, 1345-1358.

\section{Scientific Research Publishing}

\section{Submit or recommend next manuscript to SCIRP and we will provide best service for you:}

Accepting pre-submission inquiries through Email, Facebook, LinkedIn, Twitter, etc. A wide selection of journals (inclusive of 9 subjects, more than 200 journals)

Providing 24-hour high-quality service

User-friendly online submission system

Fair and swift peer-review system

Efficient typesetting and proofreading procedure

Display of the result of downloads and visits, as well as the number of cited articles

Maximum dissemination of your research work

Submit your manuscript at: http://papersubmission.scirp.org/

Or contact as@scirp.org 